\title{
PENGARUH BAURAN PEMASARAN (MARKETING MIX) TERHADAP KEPUTUSAN KONSUMEN MEMBELI JAMU INSTAN PRODUKSI KELOMPOK JATI HUSADA MULYA DESA ARGOMULYO KECAMATAN SEDAYU KABUPATEN BANTUL
}

\author{
Nola Sevilestari Cahyaningrum ${ }^{1}$, Endah Puspitojati, Miftakhul Arifin \\ Program Studi Penyuluhan Pertanian Berkelanjutan Politeknik Pembangunan Pertanian Yogyakarta-Magelang \\ Jl. Kusumanegara No. 2 Tahunan, Kecamatan Umbul Harjo, Yogyakarta 55167
}

Koresponden Email: nolascahya@gmail.com

\begin{abstract}
Abstrak
Kajian ini bertujuan untuk megetahui pengaruh bauran pemasaran (marketing mix) terhadap keputusan konsumen membeli jamu instan produksi Kelompok Jati Husada Mulya. Penelitian dilaksanakan pada Kelompok Jati Husada Mulya Desa Argomulyo Kecamatan Sedayu Kabupaten Bantul. Metode penelitian yang digunakan adalah diskriptif kuantitatif dan hubungan kausan (sebab-akibat) dengan teknik pengambilan sampel dilakukan secara accidental sampling berjumlah 32 responden. Hasil menunjukan bahwa variabel harga secara parsial berpengaruh signifikan terhadap keputusan konsumen membeli jamu instan JHM. Secara simultan variabel 4P (product, price, promotion, place) berpengaruh signifikan terhadap keputusan konsumen membeli jamu instan produksi Kelompok Jati Husada Mulya. Pengaruh variabel produk, harga, promosi, dan lokasi terhadap keputusan konsumen dalam membeli jamu instan produksi Kelompok Jati Husada Mulya sebesar 59,6\%, sedangkan 40,4\% sisanya dipengaruhi oleh faktor atau variabel lain yang tidak tercantumkan dalam kajian ini.
\end{abstract}

Kata Kunci: Pengaruh, Bauran Pemasaran. Keputusan Konsumen, Jamu Instan

\begin{abstract}
This study aimed to determine the effect of the marketing mix on consumer decisions to purchase instant herbal medicine produced by the Jati Husada Mulya Group. The research was conducted in the Jati Husada Mulya Group, Argomulyo Village, Sedayu District, Bantul Regency. The research used descriptive quantitative and causal relationship (cause and effect) methods with the sampling technique was performed by accidental sampling with 32 respondents. The results showed that the price variable partially had a significant effect on consumer decisions to buy JHM instant herbal medicine. Simultaneously, the 4P variables (product, price, promotion, place) had a significant effect on consumer decisions to buy instant herbal medicine produced by the Jati Husada Mulya Group. The effect of product, price, promotion, and location variables on consumer decisions in purchasing instant herbal medicine produced by the Jati Husada Mulya Group was 59.6\%, while the rest of $40.4 \%$ was influenced by other factors or variables not listed in this study.
\end{abstract}

\section{Keywords: Effect, Marketing Mix, Consumer Decisions, Instant Herbal Medicine}

\section{PENDAHULUAN}

Jamu merupakan ramuan tradisional kesehatan yang telah dikenal secara turun temurun dan digunakan oleh masyarakat Indonesia untuk memenuhi kebutuhan akan kesehatan. Gaya hidup yang kembali ke alam (back to nature) menyadarkan masyarakat akan pentingnya penggunaan bahan alami (obat tradisional) sebagai obat. Animo masyarakat yang meningkat terhadap penggunaan obat alami membuat perkembangan industri herbal medicine dan healthy food di Indonesia juga semakin meningkat sehingga peluang pengembangan obat tradisional Indonesia masih terbuka lebar [1].

Di desa Argomulyo, terdapat puluhan warga yang dalam keseharian bekerja sebagai pengrajin jamu tradisional [2]. Salah satunya yang tergabung dalam Kelompok Jati Husada Mulya (JHM) yang beranggotakan 30 orang [3]. Menurut hasil wawancara dari Ketua Kelompok JHM mampu memproduksi $80-100$ pack atau setara dengan 800-1000 sachet setiap kali produksinya. Namun kenyataan yang ada bahwa permintaan pasar atau permintaan konsumen atas jamu yang dihasilkan masih rendah. Penjualan produk terendah selama ini tercatat 
kurang lebih 40 pack dan tertinggi tercatat 610 pack dalam sebulan. Kondisi ini membuat usaha jamu di Kelompok Jati Husada Mulya sulit berkembang. Produk jamu yang dihasilkan banyak yang tidak terjual dan akhir membuat proses produksi terhambat, karena anggaran menjadi terhambat juga.

Berdasarkan uraian kondisi yang terjadi pada usaha jamu Kelompok Jati Husada Mulya, maka perlu dilakukan kajian dalam rangka keberlangsungan usaha. Adapun harapan yang seharusnya terjadi adalah hasil produksi jamu instan dapat dipasarkan dan terjadi peningkatan permintaan konsumen. Salah satu cara yang dapat dilakukan untuk meningkatkan pemasaran adalah melalui kajian bauran pemasaran (Marketing Mix) terhadap produk jamu yang dihasilkan [4]. Kajian ini akan menganalisis bagaimana keputusan konsumen membeli jamu instan Yang dihasilkan oleh Kelompok JHM. Dengan melakukan kajian ini, nantinya diharapkan dapat ditemukan strategi pemasaran yang tepat. Maka itu perlu dilakukan kajian tentang "Pengaruh Bauran Pemasaran (Marketing Mix) terhadap Keputusan Konsumen Membeli Jamu Instan Produksi Kelompok Jati Husada Mulya Desa Argomulyo Kecamatan Sedayu Kabupaten Bantul”.

\section{MATERIAL DAN METODE}

Kajian ini dilaksanakan pada Desember 2020 s.d Juni 2021 di Desa Argomuyo, Kecamatan Sedayu, Kabupaten Batul, Daerah Istimewa Yogyakarta. Metode kajian yang digunakan adalah metode deskriptif kuantitatif dan metode hubungan kausal (sebab akibat). Dalam kajian ini, hubungan kausal digunakan untuk mengetahui pengaruh variabel bauran pemasaran (X) meliputi produk, harga, lokasi, promosi terhadap keputusan konsumen membeli jamu instan JHM (Y).

Jumlah sampel inti ditentukan menggunakan Nomogram Herry King dengan populasi konsumen tetap jamu instan JHM sebanyak 80 orang dan mendapat hasil 32 orang sampel. Respoden dipilih dengan teknik Non-probability sampling, yaitu dengan menggunakan teknik Accidental Sampling.

Sebelum melakukan pengujian hipotesis, terlebih dahulu dilakukan proses transformasi data ordinal ke interval dengan metode saksesif (Method of Successive Internal/MSI). Analisis data yang digunakan dalam kajian ini adalah $\mathrm{Uji}$ regresi linier berganda dengan bentuk persamaan sebagai berikut [5]

$Y=a+b_{1} X_{1}+b_{2} X_{2}+b_{2} X_{2}+b_{4} X_{4}+e \ldots$. Pers. 1

Dimana :

$\mathrm{Y}=$ keputusan pembelian Konsumen

a $=$ konstanta dari keputusan regresi

$\mathrm{b} 1=$ koefisien variabel X1 (produk)

$\mathrm{b} 2$ = koefisien variabel X2 (harga)

b3 = koefisien variabel X3 (promosi)

b4 = koefisian variabel X4 (lokasi)

e $=$ variabel pengganggu

\section{HASIL DAN PEMBAHASAN Analisis Deskriptif Faktor-Faktor Keputusan Pembelian oleh Konsumen}

Produk

Hasil survei pendapat masyarakat tentang aspek produk jamu produksi kelompok JHM disajikan pada Tabel 1. Berdasarkan Tabel 1 menunjukkan bahwa tingkat pencapaian aspek produk adalah masuk dalam kategori sangat tinggi yaitu 91\%. Produk yang berkualitas akan meningkatkan harga produk [6].

Tabel 1. Distribusi Frekuensi Aspek Produk.

\begin{tabular}{cccc}
\hline No & Interval & Kategori & Jlh \\
\hline 1. & $88 \%-100 \%$ & ST & 23 \\
2. & $71 \%-87 \%$ & T & 9 \\
3. & $54 \%-70 \%$ & S & 0 \\
4. & $37 \%-53 \%$ & R & 0 \\
5. & $20 \%-36 \%$ & SR & 0 \\
& Jumlah & & 32 \\
& Persentase & ST & $91 \%$ \\
\hline
\end{tabular}

Selanjutnya hasil survei tentang kondisi produk menurut konsumen disajikan pada Tabel 2. Berdasarkan Tabel 2 menunjukkan bahwa komponen pengemasan, variasi produk, dan kualitas produk mencapai kategori sangat tinggi, dengan nilai persentase, yaitu 93\%, 92\%, dan 91\%. Semntara untuk komponen ketersediaan prosuk masuk dalam kategori tinggi, dengan nilai persentase $81 \%$. Hal ini menunjukkan bahwa menurut persepsi konsumen pada aspek produk, jamu produksi kelompok JHM adalah sangat baik dengan rata-rata $89 \%$. Hal ini dapat diartikan bahwa produk jamu instan JHM memiliki nilai tinggi karena kemasan baik, variasi beragam, kualitas baik, dan ketersediaan. 


$\begin{array}{lll}\text { Info Artikel } & \text { Received } & : 31 \text { Juli } 2021 \\ & \text { Revised } & : 29 \text { November 2021 } \\ & \text { Accepted } & : 01 \text { Desember 2021 }\end{array}$

Berdasarkan survei ini, dapat dikatakan bahwa jamu instan produksi kelompok JHM, sudah memenuhi keinginan dan kebutuhan konsumen. Hal tersebut sejalan dengan pernyataan [7], kualitas produk adalah suatu kondisi dari sebuah barang berdasarkan pada penilaian atas kesesuainnya dengan standar ukur yang telah ditetapkan. Semakin sesuai standar yang ditetapkan maka akan dinilai produk tersebut semakin berkualitas.

Tabel 2. Kondisi Produk Menurut Konsumen.

\begin{tabular}{clcc}
\hline No. & $\begin{array}{l}\text { Komponen } \\
\text { Produk }\end{array}$ & \multicolumn{1}{l}{$\begin{array}{l}\text { Persentase } \\
(\%)\end{array}$} & Kategori \\
\hline 1. & $\begin{array}{l}\text { Packaging/Penge } \\
\text { masan }\end{array}$ & 93 & ST \\
2. & Variasi & 92 & ST \\
3. & Kualitas Produk & 91 & ST \\
4. & Ketersediaan & 81 & $\mathrm{~T}$ \\
& Produk & & \\
& Rerata & 89 & ST \\
\hline
\end{tabular}

\section{Harga}

Pengolahan data hasil survei pendapat masyarakat tentang aspek harga jamu produksi kelompok JHM dapat dilihat pada Tabel 3 . Berdasarkan Tabel 3 menunjukkan bahwa jamu produksi kelompok JHM masuk ke dalam kategori sangat tinggi yaitu $88 \%$

Tabel 3 Distribusi Frekuensi Aspek Harga.

\begin{tabular}{cccc}
\hline No. & Interval & Kategori & Jlh \\
\hline 1. & $88 \%-100 \%$ & $\mathrm{ST}$ & 17 \\
2. & $71 \%-87 \%$ & $\mathrm{~T}$ & 14 \\
3. & $54 \%-70 \%$ & $\mathrm{~S}$ & 1 \\
4. & $37 \%-53 \%$ & $\mathrm{R}$ & 0 \\
5. & $20 \%-36 \%$ & $\mathrm{SR}$ & 0 \\
& Jumlah & & 32 \\
& Persentase & $\mathrm{ST}$ & $88 \%$ \\
\hline
\end{tabular}

Hasil pendapat masyarakat tentang kondisi harga berdasarkan komponennya disajikan pada Tabel 4. Berdasarkan Tabel 4 dapat dilihat bahwa komponen kesesuaian harga memiliki nilai persentase 91\% dengan kategori sangat tinggi, komponen keterjangkauan harga meiliki nilai persentase $90 \%$ dengan kategori $90 \%$, dan kemampuan harga berkompetisi $79 \%$ dengan kategori tinggi. Kondisi harga secara rata-rata masuk kategori tinggi dengan nilai persentase $87 \%$. Hal ini membuktikan bahwa dari aspek
Jurnal Agrica Ekstensia

Vol. 15 No. 2 Tahun 2021

p-ISSN $\quad: 1978-5054$

: 2715-9493 harga, jamu produksi kelompok JHM masih dapat memenuhi kebutuhan konsumen.

Jamu yang dihasilkan oleh kelompok JHM dapat diartikan sesuai dengan manfaat dan relative terjangkau bagi konsumen. Harga yang ditawarkan untuk mendapatkan jamu instan JHM adalah sekitar Rp15.000 - Rp25.000 untuk setiap box yang berisi 10 kemasan. Menurut konsumen harga tersebut cukup terjangkau, karena dengan kisaran harga yang ditawarkan konsumen bisa mendapatkan manfaat maupun khasiat dari produk jamu instan JHM yang berkualitas. Hal ini mneunjukkan bahwa dari aspek harga, jamu produksi kelompok JHM, dapat bersaing dengan jamu instan produk lain. Jamu produksi kelompok JHM, menurut masyarakat relatif lebih mahal dibanding jamu produk lain yang berproduksi di Yogyakarta. Kondisi ini dikarenakan bahan baku yang digunakan adalah alami tanpa pemanis dan disebabkan oleh produksi yang dalam jumlah kecil sehingga satuan biayanya menjadi lebih besar.

Menurut [8] dari sudut pandang konsumen, harga sering kali digunakan sebagai indikator nilai bilamana harga tersebut dihubungkan dengan manfaat yang dirasakan atas suatu barang atau jasa. Dengan demikian dapat disimpulkan bahwa pada tingkat harga tertentu, bila manfaat yang dirasakan konsumen meningkat maka nilainya akan meningkat. Harga yang ditentukan untuk mendapatkan suatu barang agar dapat diterima konsumen harus disesuaikan dengan kualitas produk, fungsi dan manfaatnya.

Tabel 4. Kondisi Harga Menurut Konsumen.

\begin{tabular}{llcc}
\hline No. & Komponen Harga & $\begin{array}{c}\text { Persentase } \\
(\%)\end{array}$ & Kategori \\
\hline 1. & Kesesuaian harga & 91 & $\mathrm{ST}$ \\
2. & $\begin{array}{l}\text { Keterjangkauan } \\
\text { harga }\end{array}$ & 90 & $\mathrm{ST}$ \\
3. & $\begin{array}{l}\text { Kemampuan } \\
\text { harga }\end{array}$ & 79 & $\mathrm{~T}$ \\
& $\begin{array}{l}\text { berkompetisi } \\
\text { Rerata }\end{array}$ & 87 & $\mathrm{~T}$ \\
\hline
\end{tabular}

Promosi

Hasil survei pendapat masyarakat mengenai aspek promosi jamu produksi kelompok JHM, disajikan pada Tabel 5. Berdasarkan Tabel 5 menunjukkan bahwa tingkat pencapaian aspek promosi dari 32 responden masuk ke dalam kategori tinggi yaitu $86 \%$. 


$\begin{array}{lll}\text { Info Artikel } & \text { Received } & : 31 \text { Juli } 2021 \\ & \text { Revised } & : 29 \text { November 2021 } \\ & \text { Accepted } & : 01 \text { Desember 2021 }\end{array}$

Tabel 5 Aspek Promosi

\begin{tabular}{cccc}
\hline No & Interval & Kategori & Jlh. \\
\hline 1. & $88 \%-100 \%$ & $\mathrm{ST}$ & 15 \\
2. & $71 \%-87 \%$ & $\mathrm{~T}$ & 16 \\
3. & $54 \%-70 \%$ & $\mathrm{~S}$ & 1 \\
4. & $37 \%-53 \%$ & $\mathrm{R}$ & 0 \\
5. & $20 \%-36 \%$ & $\mathrm{SR}$ & 0 \\
& Jumlah & & 32 \\
& Persentase & Tinggi & $86 \%$ \\
\hline
\end{tabular}

Rekapitulasi pendapat masyarakat tentang kondisi promosi jamu produksi kelompok JHM berdasarkan komponennya disajikan pada Tabel 6. Berdasarkan Tabel 6 rekapitulasi hasil data dari variabel promosi, keseluruhan komponen mendapat kategori tinggi, Komponen potongan harga mendapat $86 \%$ dan iklan mendapat $85 \%$. Secara keseluruhan aspek promosi memiliki kategori tinggi dengan persentase $86 \%$. Hal ini menunjukkan bahwa promosi yang dilakukan telah dapat menarik perhatian konsumen untuk membeli jamu instan JHM.

Kegiatan promosi berupa potongan harga dan iklan pada media cetak dan on-line telah dilakukan dalam kegiatan pemasaran jamu oleh kelompok JHM. Sehingga masyarakat telah mengenal jamu dari kelompok JHM. Konsumen membeli jamu produksi JHM salah satunya adalah karena adanya potongan harga. Komponen promosi potongan harga ini membuat daya tarik yang lebih terhadap produk jamu. Selain itu kegiatan iklan jamu produksi kelompok JHM melalui media cetak maupun media online, menurut masyarakat juga menjadi penarik untuk membeli jamu produksi kelompok JHM. Seperti yang dijelaskan [9] bahwa, promosi adalah suatu komunikasi informasi penjual dan pembeli yang bertujuan untuk merubah sikap dan tingkah laku pembeli, yang tadinya tidak menjadi mengenal sehingga menjadi pembeli dan tetap mengingat produk tersebut.

Tabel 6 Kondisi Promosi Menurut Konsumen

\begin{tabular}{llcc}
\hline No. & $\begin{array}{l}\text { Komponen } \\
\text { Promosi }\end{array}$ & $\begin{array}{l}\text { Persentase } \\
(\%)\end{array}$ & Kategori \\
\hline 1. & Potongan Harga & 86 & $\mathrm{~T}$ \\
2. & Iklan & 85 & $\mathrm{~T}$ \\
& Rerata & 86 & $\mathrm{~T}$ \\
\hline
\end{tabular}

Jurnal Agrica Ekstensia

Vol. 15 No. 2 Tahun 2021

p-ISSN $\quad: 1978-5054$

e-ISSN

\section{Lokasi (Place)}

Pendapat masyarakat tentang jamu produksi kelompok JHM berdasarkan pada aspek lokasi pemasaran disajikan pada Tabel 7. Berdasarkan Tabel 7 menunjukkan bahwa tingkat pencapaian pada aspek lokasi jamu produksi kelompok JHM masuk ke dalam kategori tinggi yaitu $83 \%$.

Tabel 7 Distribusi Frekuensi Aspek Lokasi.

\begin{tabular}{lccc}
\hline No. & Interval & Kategori & Jlh \\
\hline 1. & $88 \%-100 \%$ & ST & 12 \\
2. & $71 \%-87 \%$ & $\mathrm{~T}$ & 16 \\
3. & $54 \%-70 \%$ & $\mathrm{~S}$ & 4 \\
4. & $37 \%-53 \%$ & $\mathrm{R}$ & 0 \\
5. & $20 \%-36 \%$ & $\mathrm{SR}$ & 0 \\
& Jumlah & & 32 \\
& Persentase & Tinggi & $83 \%$ \\
\hline
\end{tabular}

Hasil pengolahan data pendapat masyarakat tentang kondisi lokasi pemasaran jamu produksi kelompok JHM berdasarkan komponennya disajikan pada Tabel 8. Berdasarkan Tabel 8, komponen kestrategisan lokasi mendapat kategori tinggi dengan nilai presentase $80 \%$ dan komponen kemudahan akses mendapat kategori sangat tinggi dengan nilai presentase 92\%. Secara keseluruhan variabel lokasi memiliki kategori tinggi dengan nilai persentase $86 \%$. Hal ini membuktikan bahwa lokasi pemasaran jamu produksi kelompok JHM, masih bisa dijangkau oleh konsumen karena strategis dan memiliki akses yang mudah. Komponen kemudahan akses menuju lokasi mendapat kategori sangat tinggi dengan persentase $92 \%$. Dengan hasil tersebut dapat diartikan bahwa menurut konsumen lokasi pemasaran jamu produksi kelompok JHM mudah diakses.

Menurut [10], bahwa lokasi yang strategis akan mendatangkan banyak konsumen sehingga mampu menaikkan grafik penjualan maupun omzet. Dipertegas oleh [11] lokasi yang strategis dapat memudahkan konsumen untuk menjangkau akses menuju perusahaan.

Tabel 8 Kondisi Lokasi Menurut Konsumen.

\begin{tabular}{llcc}
\hline No. & \multicolumn{1}{c}{$\begin{array}{c}\text { Komponen } \\
\text { Lokasi }\end{array}$} & $\begin{array}{c}\text { Persentase } \\
(\%)\end{array}$ & Kategori \\
\hline 1. & $\begin{array}{l}\text { Kestrategisan } \\
\text { lokasi }\end{array}$ & 80 & $\mathrm{~T}$ \\
2. & $\begin{array}{l}\text { Kemudahan akses } \\
\text { menuju lokasi } \\
\text { Rerata }\end{array}$ & 92 & $\mathrm{ST}$ \\
\hline
\end{tabular}




$\begin{array}{lll}\text { Info Artikel } & \text { Received } & : 31 \text { Juli } 2021 \\ & \text { Revised } & : 29 \text { November 2021 } \\ & \text { Accepted } & : 01 \text { Desember 2021 }\end{array}$

Keputusan Konsumen dalam Pembelian Jamu Produksi Kelompok JHM

\section{Keputusan Konsumen}

Hasil pendapat masyarakat tentang keputusan dalam pembelian jamu produksi JHM disajikan pada Tabel 9. Berdasarkan Tabel 9 dapat dilihat, bahwabahwa tingkat pencapaian keputusan konsumen membeli jamu produksi kelompok JHM masuk ke dalam kategori tinggi dengan nilai presentase $87 \%$.

Tabel 9 Frekuensi Keputusan Konsumen

\begin{tabular}{cccc}
\hline No. & Interval & Kategori & Jlh \\
\hline 1. & $88 \%-100 \%$ & ST & 15 \\
2. & $71 \%-87 \%$ & $\mathrm{~T}$ & 15 \\
3. & $54 \%-70 \%$ & $\mathrm{~S}$ & 2 \\
4. & $37 \%-53 \%$ & $\mathrm{R}$ & 0 \\
5. & $20 \%-36 \%$ & $\mathrm{SR}$ & 0 \\
& Jumlah & & 32 \\
& Persentase & $\mathrm{T}$ & $87 \%$ \\
\hline
\end{tabular}

Rekapitulasi kondisi keputusan konsumen berdasarkan komponen keputusan disajikan pada Tabel 10. Berdasarkan Tabel 10, dapat dilihat bahwa komponen ketertarikan masuk kategori sangat tinggi dengan nilai persentase $88 \%$. komponen keputusan pembelian masuk kategori tinggi dengan nilai persentase $85 \%$, dan komponen pasca beli masuk kategori sangat tinggi dengan persentase $88 \%$. Secara rerata aspek keputusan konsumen masuk kategroti tinggi dengan nilai persentase $87 \%$. Hal ini menunjukkan bahwa konsumen melakukan keputusan pembelian karena konsumen merasa tertarik dan ingin memenuhi kebutuhan mereka.

Berdasarkan rekapitulasi data variabel keputusan konsumen, komponen ketertarikan mendapat kategori sangat tinggi dengan persentase $88 \%$. Komponen keputusan pembelian mendapat kategori tinggi dengan persentase $85 \%$. Komponen pasca beli mendapat kategori sangat tinggi dengan persentase $88 \%$.

Dari hasil keseluruhan pada variabel keputusan konsumen mendapat kategori tinggi dengan persentase $87 \%$. Hal tersebut dapat diartikan konsumen tertarik untuk membeli produk jamu intan JHM karena produk berniilai tinggi, harga terjangkau, promosi menarik, dan lokasi strategis

Hal tersebut membuktikan bahwa konsumen melakukan keputusan pembelian karena konsumen merasa tertarik dan ingin memenuhi kebutuhan mereka. Hal tersebut sejalan dengan pendapat [12] yang menyatakan bahwa proses pembelian dimulai saat pembeli menggali masalah atau kebutuhan. Pengenalan kebutuhan akan terjadi ketika konsumen mengahadapi ketidakseimbangan antara keadaan sebenarnya dan keinginan, sehingga konsumen akan berusaha memenuhi kebutuhannya dengan melakukan proses pembelian.

Tabel 10 Kondisi Keputusan Konsumen

\begin{tabular}{|c|c|c|c|}
\hline No. & $\begin{array}{l}\text { Komponen } \\
\text { Keputusan }\end{array}$ & $\begin{array}{c}\text { Persentase } \\
(\%)\end{array}$ & Kategori \\
\hline 1. & Ketertarikan & 88 & ST \\
\hline 2. & $\begin{array}{l}\text { Keputusan } \\
\text { Pembelian }\end{array}$ & 85 & $\mathrm{~T}$ \\
\hline \multirow[t]{2}{*}{3.} & Pasca Beli & 88 & $\mathrm{ST}$ \\
\hline & Rerata & 87 & $\mathrm{~T}$ \\
\hline
\end{tabular}

Pengaruh Faktor - Faktor Keputusan Konsumen Secara Simultan

Hasil pengolahan data, diperoleh $F_{\text {hitung }}$ sebesar 9,952 dan dengan menggunakan Tabel $\mathrm{F}$ diperoleh $\mathrm{T}_{\text {Tabel }}$ sebesar 2,71. $\mathrm{F}_{\text {hitung }}$ lebih besar dari $\mathrm{F}_{\text {Tabel. }}$ Artinya Ho ditolak dan Ha diterima. Hal tersebut dapat diartikan bahwa bauran pemasaran yang meliputi aspek produk, harga, promosi, dan lokasi secara simultan berpengaruh signifikan terhadap keputusan konsumen dalam membeli jamu instan produksi Kelompok JHM. Dapat dinyatakan bahwa hasil pengujian menunjukkan, bahwa faktor produk, harga, promosi, dan lokasi secara simultan memiliki pengaruh yang signifikan terhadap keputusan konsumen.

Hasil kajian ini sejalan dengan pendapat [11] yang menyatakan bahwa produk yang dikelola perusahaan akan langsung melibatkan konsumen. Tujuannya adalah untuk mencapai keputusan konsumen. Melalui strategi produk yang dilakukan oleh perusahaan, konsumen akan mempertimbangkan untuk membeli ataupun tidak yang disesuaikan dengan kebutuhan maupun keinginannya. Selanjutnya, variabel yang kedua adalah harga yang mempengaruhi konsumen dalam keputusan pembelian. Penentuan harga yang dilakukan perusahaan memiliki hubungan dengan keputusan konsumen. Ketiga promosi yang merupakan salah satu variabel bauran pemasaran untuk mempengaruhi konsumen. Promosi dilakukan dengan cara menyediakan informasi yang bersifat persuasif. Promosi dilakukan dengan tujuan untuk mempengaruhi pasar dan 
memperoleh respons Kemudian lokasi merupakan tempat dimana suatu usaha atau aktivitas usaha dilakukan dengan penyediaan produk atau jasa yang dibutuhkan konsumen. Oleh karena itu, lokasi merupakan hal yang penting sebagai pertimbangan konsumen untuk mengambil keputusan

Pada penelitian ini, diperoleh persamaan regresi keputusan konsumen dalam pembelian jamu produksi kelompok JHM yang dipengaruhi oleh faktor produk, harga, promosi da lokasi sebagai berikut:

$$
\begin{gathered}
Y=205,6+13,3 X_{1}+91,7 X_{2}+20,5 X_{3} \\
+7,8 X_{4} \ldots \text { Pers } 2
\end{gathered}
$$

Dari persamaan regresi dapat diketahui bahwa, Y merupakan variabel keputusan pembelian yang nilainya akan diprediksi oleh variabel bauran pemasaran (marketing mix) yang meliputi aspek produk, harga, promosi, lokasi. Nilai 205,6 yang merupakan konstanta (a) yaitu estimasi dari persentase keputusan pembelian jika semua variabel bebas diasumsikan bernilai nol. Nilai 13,3 adalah koefisien produk (b1), nilai 91,7 koefisien harga (b2), nilai 20,5 koefisien promosi (b3), dan nilai 7,8 koefisien lokasi (b4). Koefisien dengan tanda positif memiliki arti apabila pada saat variabel bebas lainnya diasumsikan bernilai nol atau konstan pada suatu nilai tertentu maka dengan meningkatnya persentase variabel bebas satu satuan akan berpengaruh meningkatkan nilai persentase variabel terikat yaitu keputusan pembelian sebesar nilai koefisien variabel bebas dikali $100 \%$.

Persamaan regresi yang dihasilkan sepreti yang disajikan pada Pers. 2 memiliki nilai $\mathrm{R}^{2}(R$ Square) atau koefisien sebesar 0,596. Koefisien determinasi tersebut menunjukkan bahwa persentase sumbangan pengaruh variabel independen yaitu produk, harga, promosi, dan lokasi terhadap keputusan konsumen dalam membeli jamu produksi kelompok JHM adalah sebesar 59,6\%. Sisanya sebesar 40,4\% dipengaruhi oleh faktor atau variabel lain yang tidak tercantumkan dalam kajian ini. Variabel lain yang mungkin mempengaruhi keputusan konsumen adalah faktor internal dan eksternal yang meliputi sumber daya manusia (pribadi dan psikologi), bukti fisik, proses, sosial budaya, dan kemungkinan lainnya.

Variabel lain yang nyata mempengaruhi keputusan konsumen dalam pembelian jamu instan JHM adalah faktor sosial budaya dan minat konsumen Desa Argomulyo terhadap jamu instan JHM. Rendahnya minat konsumen tersebut diakibatkan karena masyarakat Desa Argomulyo lebih tertarik terhadap jamu gendong keliling yang bisa mereka dapatkan setiap hari dengan langsung meminumnya. Masyarakat bisa mendapatkan jamu gendong dengan harga yang lebih murah, khasiat yang sama, dan langsung didatangi oleh penjual, sehingga masyarakat tidak merasa kerepotan.

Pernyataan hasil kajian diatas didukung oleh pendapat [13] bahwa konsumen mendapat rangsangan dari luar yang terdiri atas bauran pemasaran (produk, harga, promosi, lokasi) ekonomi, teknologi, politik, budaya, yang mempengaruhi kotak hitam pembeli (kebudayaan, sosial, pribadi, dan psikologis) dan menghasilkan tanggapan dari pembeli untuk melakukan keputusan pembelian.

\section{Pengaruh Faktor-Faktor Keputusan Konsumen Secara Partial}

Hasil uji t untuk menguji secara partial faktorfaktor yang mempengaruhi keputusan konsumen dalam pembelian jamu produksi kelompok JHM, disajikan pada Tabel 11.

Tabel 11. Hasil Uji t

\begin{tabular}{lcccc}
\hline \multicolumn{1}{c}{ Variabel Bebas } & $\mathrm{t}_{\text {hitung }}$ & $\mathrm{t}$ tabel & Perbandingan & Keterangan \\
\hline Produk (X1) & 1,146 & 2,052 & $\mathrm{t}$ hitung $<\mathrm{t}$ tabel & Ditolak \\
Harga (X2) & 2,704 & 2,052 & $\mathrm{t}$ hitung $>\mathrm{t}$ tabel & Diterima \\
Promosi (X3) & 0,853 & 2,052 & $\mathrm{t}$ hitung $<\mathrm{t}$ tabel & Ditolak \\
Lokasi (X4) & 0,232 & 2,052 & $\mathrm{t}$ hitung $<\mathrm{t}$ tabel & Ditolak \\
\hline
\end{tabular}

Pada Tabel 11, dapat dilihat pada nilai $t_{\text {hitung }}$ lebih kecil dari dan $\mathrm{t}_{\text {tabel }} \mathrm{l}(1,146<2,052)$. Sehingga Ho diterima dan Ha ditolak, yang artinya variabel produk tidak berpengaruh signifikan terhadap keputusan konsumen membeli jamu produksi Kelompok JHM. Hal ini dikarenakan produk jamu instan JHM hanya bisa dibeli disaat tertentu ketika dibutuhkan 


\begin{tabular}{lll} 
Info Artikel & Received & $: 31$ Juli 2021 \\
& Revised & $: 29$ November 2021 \\
& Accepted & $: 01$ Desember 2021 \\
\hline
\end{tabular}

manfaatnya saja dan bukan menjadi sebuah keharusan untuk dikonsumsi oleh konsumen. Menurut [11] konsumen memilih produk yang memiliki manfaat berdasarkan fungsi kebutuhannya. Produk yang berkarakteristik baik dan berkualitas lebih dipilih oleh konsumen.

Selanjutnya pada variabel harga dapat dilihat pada Tabel 11, bahwa $t_{\text {htiung }}$ lebih besar dari tabel (2,704 > 2,052). Sehingga Ho ditolak dan Ha diterima, yang artinya secara parsial variabel harga berpengaruh signifikan terhadap keputusan konsumen membeli jamu produksi kelompok JHM. Hal ini terjadi karena, konsumen mempertimbangkan keputusan membeli berdasarkan harga yang ditawarkan. Sebab harga mampu mempengaruhi psikologis konsumen untuk membeli. Semakin murah dan berkualitas maka minat konsumen untuk membeli akan semakin tinggi. Produk jamu Jroduksi kelompok JHM memiliki harga terjangkau yang sesuai dan berkualitas serta memberikan manfaat bagi konsumen, sehingga menjadi pengaruh bagi konsumen dalam mengambil keputusan. Kondisi sesuai dengan pernyataan [10], bahwa keputusan pembelian tersebut didasari oleh beberapa indikator yaitu kesesuaian harga, harga yang terjangkau, dan harga yang kompetitif. Harga akan menciptakan pandangan konsumen terhadap suatu produk dan dapat mempengaruhi keputusan pembelian.

Pada Tabel 11 dapat dilihat juga, bahwa untuk variabel promosi, $t_{\text {hitung }}$ lebih kecil dari $t_{\text {tabel }}($ $0,853<2,052)$. Sehingga keputusannya adalah Ho diterima dan Ha ditolak, yang artinya variabel promosi tidak berpengaruh secara signifikan terhadap keputusan konsumen membeli jamu produksi Kelompok JHM. Hal tersebut terjadi karena promosi yang dilakukan kelompok JHM belum optimal, sehingga konsumen tidak terlalu bergantung pada jamu yang mereka produksi. Pemberian potongan harga, dan iklan melalui media cetak maupun online seharusnya dapat diupayakan lebih optimal oleh kelompok JHM. Berdasarkan penjelasan [10] Promosi dapat dilakukan dengan cara pemberian potongan harga dan pemberian bonus atau kupon tertentu. Promosi dapat dilakukan melalui media cetak maupun media elektronik. Semakin menarik dan sering promosi dilakukan maka akan semakin meningkatkan penjualan produk.

Untuk variabel Lokasi, berdasarkan Tabel 11 dapat dilihat memiliki nilai $t_{\text {hitung }}$ lebih kecil dari $t_{\text {tabel }}(0,232<2,052)$. Sehingga Ho diterima dan Ha ditolak, yang artinya variabel lokasi tidak
Jurnal Agrica Ekstensia

Vol. 15 No. 2 Tahun 2021

$\begin{array}{ll}\text { p-ISSN } & : 1978-5054 \\ \text { e-ISSN } & : 2715-9493\end{array}$

berpengaruh secara signifikan terhadap keputusan pembelian konsumen. Hal tersebut dikarenakan ada atau tidaknya keberadaan jamu untuk dibeli oleh konsumen pada penjual jamu gendong atau berkeliling di wilayah Desa Argomulyo. Namun jika dilihat pada sisi dimensi lokasi tempat usaha, usaha jamu kelompok JHM berada pada lokasi yang strategis sehingga dapat dijadikan pertimbangan konsumen dalam memutuskan pembelian. Hal ini sejalan dengan pernyataan [11] lokasi meliputi dimana pemasar memasarkan produknya dan konsumen datang untuk memutuskan pembelian. Pemilihan lokasi strategis yang dilakukan perusahaan, akan menjadi penentu minat konsumen untuk melakukan pembelian. Lokasi yang strategis dapat memudahkan konsumen untuk menjangkau akses menuju perusahaan.

\section{Kesimpulan \\ KESIMPULAN DAN SARAN}

1. Deskripsi faktor-faktor keputusan pembelian oleh konsumen adalah:

a. Kondisi produk masuk kategori sangat tinggi dengan nilai persentase $91 \%$;

b. Kondisi harga masuk kategori sangat tinggi dengan nilai persentase $88 \%$;

c. Kondisi promosi masuk kategori tinggi dengan nilai persentase $86 \%$;

d. Kondisi tempat masuk kategori tinggi dengan nilai persentase $83 \%$.

2. Keputusan konsumen dalam pembelian jamu produksi Kelompok JHM adaalh:

a. Keputusan membeli jamu produksi kelompok JHM masuk kategori tinggi nilai persentase $87 \%$;

b. Secara simultan faktor produk, harga, promosi, dan lokasi, mempengaruhi keputusan konsumen dalam pembelian jamu produk kelompok JHM;

c. Secara parsial faktor produk, promosi, da lokasi tidak berpengaruh nyata terhadap keputusan pembelian jamu produksi kelompok JHM, sementara faktor harga berpengaruh secara signifikan.

\section{Saran}

1. Untuk meningkatkan keputusan konsumen terhadap pembelian jamu produksi kelompok JHM, perlu usaha untuk menurunkan harga jual jamu; 


\begin{tabular}{lll} 
Info Artikel & Received & $: 31$ Juli 2021 \\
& Revised & $: 29$ November 2021 \\
& Accepted & $: 01$ Desember 2021 \\
\hline
\end{tabular}

\section{DAFTAR PUSTAKA}

[1] Kementerian Kesehatan Repubik Indonesia. 2015. Pembuatan Jamu Segar yang Baik dan Benar. Jakarta

[2] Badan Pusat Statistik Kabupaten Bantul. 2020. Kabupaten Bantul dalam Angka 2020. BPS. Bantul.

[3] Kecamatan Sedayu. 2018. Profil Kecamatan Sedayu 2018. Kecamatan Sedayu Kabupaten Bantul.

[4] Mas'ari, Ahmad, dkk. 2019. Analisa Strategi Marketing Mix Menggunakan Konsep 4P (Price, Product, Place, Promotion) pada PT. Haluan Riau. Jurnal Teknik Industri. Fakultas Sains dan Teknologi. Universitas Islam Negeri Seltan Syarif Kasim Riau. Pekanbaru.

[5] Sugiyono. 2018. Metode Penelitian Kuantitatif, Kualitatif, dan R\&D. PT. Alfabeta. Bandung

[6] Rahayu, Sri. 2017. Hubungan Kualitas Produk dan Harga dengan Minat Beli Konsumen pada CV. Morojoyo Tas di Dupak Grosir Lt. 1 Blok BG No. 35 Surabaya. Skripsi. Universitas Narotama. Surabaya.

[7] Handoko. 2002. Manajemen Pemasaran. Badan penerbit IPWI. Jakarta

[8] Santoso, Kresniawan Wibowo dkk. 2013. Pengaruh Kualitas Produk, Harga dan
Jurnal Agrica Ekstensia

Vol. 15 No. 2 Tahun 2021

p-ISSN : 1978-5054

: 2715-9493

Promosi Terhadap Keputusan Pembelian Permen Tolak Angin di Semarang.

[9] Hadisantoso, Othniel. 2010. Pengaruh Variabel Marketing Mix terhadap Volume Penjualan di PT Rukun Sejahtera Sentisa Surabaya: Skripsi. Universitas Narotama. Surabaya.

[10] Utami, Arum Puspa. 2016. Pengaruh Bauran Pemasaran terhadap Keputusan Pembelian Konsumen di Minimarket Kopma Universitas Negeri Yogyakarta: Skipsi. Fakultas Ekonomi. Universitas Negeri Yogyakarta.

[11] Sholihah, Nur Wahidatus. 2019. Pengaruh Marketing Mix 4P (Product, Price, Place dan Promotion) terhadap Keputusan Konsumen yang menjadi Jama'ah Umroh di PT. Shafira Lintas Semesta. Fakultas Dakwah dan Komunikasi. Universitas Islam Negeri Sunan Ampel Surabaya.

[12] Kotler, Philip. 2004. Marketing Management, Millenium Edition. University of Phoenix. United States of America

[13] Kotler, Philip dan Gary Amstrong. 2007 Marketing, Terjemahan: Herujati, Jilid 1 Cetakan Kesepuluh. Jakarta: Penerbit Erlangga 